\title{
O MATRONEJU KATEDRALE U ZADRU
}

Ana MIŠKOVIĆ

Odjel za povijest umjetnosti

Sveučilište u Zadru

Zadar, Hrvatska
UDK: 2-523(497.5 Zadar)

DOI: https://dx.doi.org/10.21857/m3v76t6e5y

Prethodno priopćenje

Prihvaćeno: 21. prosinca 2018.

U radu se analizira i problematizira vrijeme nastanka galerija katedrale u Zadru te utjecaji koji su mogli biti presudni na njihovu izgradnju. Citatima bizantskih povijesnih vrela i tumačenjima dijelova obreda $s$ istog područja podupire se u literaturi prethodno postavljena teza o kasnoantičkoj dataciji matroneja zadarske stolne crkve. U prilog tome idu i izrazi za galerije zabilježeni u zadarskoj povijesnoj baštini - kao što je gynecei, termin koji potvrđuje arhaičnost iz grčkog/bizantskog govornog područja te ujedno označava smještaj žena u određenom prostoru crkve, u ovom slučaju na gornjoj etaži bočnih brodova katedrale.

Ključne riječi: matronej, oratorij, galerije, katedrala, ranokršćanska bazilika.

U svome radu „Po čemu je u 10. st. katedrala u Zadru mogla sličiti halkopratejskoj bazilici u Carigradu“ Pavuša Vežić pretpostavlja da je „srednjovjekovna katedrala u Zadru zapravo romanizirani oblik one ranokršćanske i njezinih ranosrednjovjekovnih interpolacija“. A Autor u radu razlaže po kojim je to osnovama zadarska katedrala (Sl. 1) mogla sličiti važnoj konstantinopolskoj bazilici (Sl. 2), odnosno koje je to arhitektonske komponente mogla imati u kasnoj antici ili ranom srednjem vijeku, a da ih je naslijedila u romanici. Uspoređujući tlocrte dviju građevina, on uviđa njihovu sličnost $\mathrm{u}$ formi longitudinalne bazilike, pri čemu je konstantinopolska bazilika znatno šira i duža, monumentalnija u svakom pogledu. Stavljajući zato u pitanje razlog njihove usporedbe ili povezanosti, autor uviđa da se barem još dvama ambijentima možda mogu pripisati zajedničke odlike. Istraživanjem je tako prepoznao ambijent eukterija na začelju sjevernog broda katedrale u Zadru, nešto što je i halkopratejska bazilika imala. ${ }^{2}$ Pažnju mu je privukao i ambijent galerija koje je halkopratejska bazilika izvorno posjedovala, dok se za zadarsku crkvu to nije znalo. Činjenica jest da je potonja u srednjem vijeku dobila galerije, no one nastaju u jednom graditeljskom zahvatu, kada se bazilici iz temelja podižu

1 Pavuša Vežić, Po čemu je u 10. st. katedrala u Zadru mogla sličiti halkopratejskoj bazilici u Carigradu, Diadora, sv. 20, Zadar, 2001., 301 - 313, 301.

2 P. VEŽIĆ, Po čemu je u 10. st. katedrala u Zadru, $302-303$. 
sjeverni bočni zid, pročelje i nova apsida. U interijeru se ukopava kripta te se interpoliraju nove kolonade koje podržavaju galerije u obliku heksafora. ${ }^{3} \mathrm{U} 13$. st. katedrala se produžava za 14 metara čime se postiže izrazitija longitudinalnost, poštujući i prihvaćajući pritom identično oblikovanje njezinih arhitektonskih elemenata kako u eksterijeru tako i u interijeru. ${ }^{4}$

Što se tiče titulara katedrale u Zadru, po predaji o prijenosu relikvija sv. Anastazije te o svečanom štovanju posvete bazilike 18. studenog - Dedicatio basilicarum Petri et Pauli - sasvim je uvjerljiva teza da je bila posvećena sv. Petru i Pavlu. ${ }^{5}$ Međutim, već sredinom 10. st. car Konstantin VII. Porfirogenet nazvao ju je hramom svete Anastazije. ${ }^{6}$

Izvorno podignuta kao trobrodna građevina čiji su brodovi podijeljeni kolonadom stupova, uistinu je bila klasičan primjer ranokršćanske bazilike. ${ }^{7}$ Širina bazilike iznosi oko $20 \mathrm{~m}$, a dužina oko $30 \mathrm{~m}$, što govori o omjerima 2 : 3. Ipak, polukružna, istaknuta apsida šireg promjera $(13,5 \mathrm{~m}$, dubina $8 \mathrm{~m})$ od raspona srednjeg broda razlikuje je od sličnih primjera, što se u istraživanjima pokazalo kao regionalna karakteristika. ${ }^{8} \mathrm{U}$ usporedbi s halkopratejskom bazilikom taj je omjer nešto drugačiji: tako je kod bazilike u Konstantinopolu

Pavuša VEŽıć, Episkopalni kompleks u Zadru, Zadar, 2013., 45.

P. VEžı́, Episkopalni kompleks u Zadru, 47.

Narratio historica o prijenosu relikvija sv. Anastazije govori da su prenesene u crkvu sv. Petra (... ad Ecclesiam B. Petri...), a Valerio de Ponte navodi predaju o posveti sub titulo Sancti Petri (Vitaliano Brunelli, Storia della città di Zara, Zara, 1913., 118). Dan svetih mučenika 29. 6. posebno je obilježen u kalendaru zadarske stolne crkve te je vrlo svečano i bio obilježen osmodnevnim slavljem, tzv. octauom koja pada na 6. 7. Posveta bazilike apostolima slavila se trećeg datuma, 18. 11. (Marijan GrGić, Kalendar zadarske stolne crkve iz 15. st., Radovi Instituta JAZU u Zadru, sv. 20., Zadar, 1973., 128 i 134). P. Vežić uvjerljivo pretpostavlja da je uz sv. Petra naslovnik bio i sv. Pavao. Pavuša VEŽić, Zadar na pragu kršćanstva. Arbitektura ranoga kršćanstva u Zadru i na zadarskome području, Zadar, 2005., 38. O kultu sv. Petra u kasnoantičkom Zadru nedavno je pisao Nikola JA Kšić (Kult sv. Petra u kasnoantičkom i srednjovjekovnom Zadru, Scripta Branimiro Gabričević dicata, Trilj, 2010., $305-310)$.

6 Mate Suić, Zadar u 'De administrando imperio" Konstantina Porfirogeneta, Radovi Zavoda JAZU u Zadru, sv. 27-28., Zadar, 1981., 6; Milenko LončAR, On the Description of the Churches of the St. Anastasia and St. Donat in Zadar in De administrando imperio by Constantine Porphyrogenitus, Hortus artium medievaium, sv. 5, Zagreb - Motovun, 1999., 235 - 243; Pavuša VEžıć, Po čemu je u 10. st. katedrala u Zadru, 301.

7 Nada Klaić - Ivo Petricioli, Zadar u srednjem vijeku do 1409., Prošlost Zadra, sv. II, Zadar, 1976., 118; Ivo PETRICIOLI, Contribution à la recherche de la plus ancienne phase de construction de la chatédrale de Zadar, Disputationes Salonitanae, sv. 2., Vjesnik za arheologiju $i$ historiju dalmatinsku, sv. 77., Split, 1984., 150 - 153.

8 Pavuša VEžıć, Starokršćanska arhitektura u Zadru i na zadarskome području, Godišnjak zaštite spomenika kulture Hrvatske, sv. 12., Zagreb, 1986., 165 - 176, Pavuša VEžić, Prilog poznavanju tipoloških oblika starokršćanskih bazilika u Dalmaciji, Rapski zbornik, Zagreb, 1987., 198 - 299. 
omjer širine i dužine 3 : $2 .{ }^{9}$ Južni zid katedrale u Zadru iz kasnoantičkih vremena danas je jednim dijelom sačuvan. Kolonade brodova vjerojatno su bile od bijelog i zelenog mramora, kao što je to zapisano u djelu Konstantina VII. Porfirogeneta: „Crkva Sv. Anastazije je bazilika slična crkvi Halkoprata, sa zelenim i bijelim stupovima, sva ukrašena starinskim slikarijama, a njezin je pod od divnih mozaika." ${ }^{10} \mathrm{U}$ bazilici su ostala sačuvana čak dva tordirana mramorna stupa (najvjerojatnije) iz te faze, premda više ne stoje na izvornom mjestu, već su prebačeni na interkolumnije romaničkog produženja. ${ }^{11} \mathrm{Na}$ osnovi analogije s ostalim ranokršćanskim bazilikama u Zadru (bazilikom sv. Stjepana i bazilikom sv. Tome), može se pretpostaviti da je pročelje bilo rastvoreno trima ulazima, premda ne postoje nikakvi materijalni tragovi toj tezi. Lukovi ili grede nad kolonadom započinjali su i završavali na polustupovima. $U$ apsidi se nalazio subselij u sklopu kojeg je vjerojatno bila katedra, a do kojeg su bile baze konstrukcije tribelona (od kojeg je in situ očuvana baza južnog stupa). Monumentalni stupovi koji su se izdizali pred apsidom naglašavali su sveti prostor oltara i mjesto nadglednika - biskupa. Vrlo duboka apsida $(8 \mathrm{~m}$ ) bila je pogodna za formiranje ambijenta ophoda koji je bio prekriven mozaicima, a tragovi kojih su sačuvani u južnom dijelu polukružnog ophoda. ${ }^{12}$

Nikola Jakšić donio je rekonstrukciju mozaika bočnih brodova na osnovi sačuvanih djelića na kraju sjevernog i južnog bočnog broda. Radi se o motivu oktogona obgrljenog kvadratićima koji u linearnom nizanju ostavlja oblike polukrugova okrenutih prema središnjem brodu. Mozaik se, po njemu, s istim

9 Thomas Francis Mathews, The Early Churches of Constantinople: Architecture and Liturgy, University Park and London, 1971., 28 - 33; P. VEžić, Po čemu je u 10. st. katedrala u Zadru, 304; Ana Miš Ković, The water well in Zadar's cathedral, Bulletin de Association pour l'Antiquité tardive, n. 25., Brepols, 2016., 29 - 51.

10 M. Suić, Zadar u "De administrando imperio", 6; M. LončAR, On the Description of the Churches, 235 - 243; P. VEžı́́, Episkopalni kompleks u Zadru, 29.

11 Zara, Catalogo delle cose d'arte e di antichità d'Italia, (autor C. Cecchelli), Roma, 1932., 22; Pavuša VEŽıć, Ranokršćanski reljefi i arhitektonska plastika u Zadru i na zadarskome području, Diadora, sv. 22., Zadar, 2007., 122.

12 Pavuša Vežıć, Prezbiterij katedrale u Zadru, Prilozi povijesti umjetnosti u Dalmaciji, sv. 30., Split, 1990., 49 - 53, P. VEžıć, Zadar na pragu kršćanstva, 39 - 41. Taj mozaik, skupa s onim očuvanim u dnu bočnih brodova bazilike i onima u katekumeneju koji su na istoj podnoj razini, po načinu komponiranja, koloritu i ornamentici spada u stil i predloške akvilejskog kruga 5. st. Ivo Petricioli, Pavimenti musivi paleocristiani della cattedrale di Zara, Atti e memorie della Società istriana di archeologia e storia patria, vol. 39., Trieste 1991., 14 - 15; KATALOG, Slikarstvo. Umjetnička baština zadarske nadbiskupije, (ur. Nikola Jakšić, autori: Emil Hilje, Radoslav Tomić), Zadar 2006., 63 - 67, (Pavuša VEŽıć, kat. 002 i 003). 
ornamentom protezao u punoj dužini obaju brodova! ${ }^{13}$ Isti autor smatra da su oni s obzirom na gust raspored stupova koji je diktirao motiv oktogona, odnosno manji polukružni motivi, morali biti povezani gredama što bi također „odgovaralo tezi o galerijama povrh“. ${ }^{14}$

Usporedba, dakle, zadarske crkve s carigradskim hramom Presvete Bogorodice Halkopratejske (sama crkva Halkoprata opisuje se u drugoj knjizi Konstantina Porfirogeneta De Ceremoniis ${ }^{15}$ ) navela je P. Vežića da u našoj katedrali pretpostavi galerije. ${ }^{16}$ Njihova izgradnja pripisana je utjecaju solunskog kulturnog kruga s obzirom na to da neke važne ranokršćanske solunske građevine (npr. bazilika sv. Dimitrija) posjeduju galerije nad bočnim brodovima. ${ }^{17}$ No prije detaljnijeg razmatranja o tome treba napomenuti da galerije u okvirima zapadne liturgije nisu pravilo, već iznimka, te bi trebali biti vrlo oprezni u pripisivanju tog specifičnog ambijenta u sklop gabarita zadarske ranokršćanske katedrale. Jedina nešto pouzdanija stavka jest činjenica da naša historiografija za zadarske galerije bilježi termin matronej i gynecei koji su povezani uz ranobizantske građevine, a upravo bi oni mogli biti argumenti da katedrali već u prvoj fazi dodamo i galerije.

Ako raspravu nastavimo na temelju usporedbe kao što je to prvi napravio $\mathrm{P}$. Vežić, ${ }^{18}$ postojanje galerija u zadarskoj katedrali mogli bismo tako pretpostaviti u njezinoj prvoj fazi izgradnje. De administrando imperio datira se u sredinu 10. st. te su galerije eventualno mogle biti podignute neposredno prije toga. Tezu o galerijama u prvom najstarijem sloju katedrale podupire i N. Jakšić, pri čemu ističe kako je zadarska katedrala u tom razdoblju jedina na istočnoj obali Jadrana koja je vjerojatno imala galerije: „Il duomo romanico di Zara ancor oggi presenta analoghe gallerie sopra le navate laterali ed è l'unica costruzione del genere nell'area dell'Adriatico orientale, il che attesterebbe che anche la cattedrale paleocristiana di Zara aveva le gallerie (in caso contrario il paragone

13 Nikola Ja KŠıć, La première cathédrale de Zadar, Antiquité tardive, vol. 16., Brepols, $2008 ., 187$ 194; N. JAKšı́́, Kult sv. Petra, 306 - 307. No, kako su se mozaični tapeti izrađivali sukscesivno, u etapama, ovisno o donacijama vjernika, oni su često bili koncipirani zapravo u dijelovima i kombinacijom različitih ornamenata i mozaičnih polja..

$14 \quad$ N. JAkšić, Kult sv. Petra, 307.

15 T. F. MATHews, The Early Churches of Constantinople, $31-32$.

16 Pavuša VEžıć, Arhitektura romaničke katedrale u Zadru, Majstor Radovan i njegovo doba, (ur. I. Babić), Trogir, 1994., 229 - 240; P. VEŽıć, Po čemu je u 10. st. katedrala u Zadru, 301 - 313.

17 Richard Krautheimer, Early Christian and Byzantin architecture, London, 1986., 124 - 127; Charalambos BAkirtzis, The Basilica of St. Demetrius, Thessaloniki, 1997.

18 Na osnovi De cerimoniis u kojoj se opisuje spomenuta konstantinopolska crkva. P. VEžıć, Po čemu je u 10. st. katedrala u Zadru, $301-313$. 
con la basilica Halcopratea sarebbe insensata), motivo fondamentale per cui le mantenne nella fase costruttiva romanica."19

U razmatranju samog citata o katedrali iz De administrando imperio valjalo bi spomenuti i onaj koji slijedi neposredno nakon njega, a radi se o opisu crkve sv. Trojstva (S1.3) koja uostalom pripada episkopalnom sklopu u Zadru. „Iuxta autem illud est aliud quoque templum rotondum S. Trinitatis, et supra illud rursum aliud instar catechumenorum, itidem rotundum, in quod cochlea ascenditur." ${ }^{\text {20 }}$

Prijevod tog citata glasi: „Jest pak i drugi hram blizu njega, presvođen, Sveto Trojstvo, i ponad samoga hrama opet drugi hram poput katekumena, i sam presvođen, u koji ulaze i zaobljenim stepeništem. “21 Iz navedenog citata mogli bismo izvući čak dvojake teze: ili pisac navodi da su u sklopu kompleksne rotonde sv. Trojstva postojala dva (prividno) zasebna svetišta - jedan u donjoj etaži (S1.4), a drugi u gornjoj (S1. 5), koja su povremeno funkcionirala neovisno jedan o drugome, ili, što je možda ipak manje vjerojatno, da se prilikom opisa galerija iz Sv. Trojstva autor referira na već uočeni ambijent galerija opet drugi hram poput katekumena, možda upravo u katedrali. Svakako, prva teza o dva prividno zasebna svetišta ima smisla jer je gornji kat bio u funkciji oratorija te su se istovremeno mogla odvijati dva ili čak više manjih obreda unutar monumentalne crkve sv. Trojstva. U prilog tome, dakle, govori i izraz tà katechoúmena jer su se tako uistinu nazivale galerije konstantinopolskih crkava. U razdoblju datacije spisa, dakle u 10. st., tà katekhoúmena ne označava

19 Jakšić također smatra da katedrala nije dobila značajne konstruktivne pregradnje sve do vremena 12. st. izuzimajući pritom interpolaciju pastoforija i nove liturgijske instalacije. Nikola JAKŠIĆ, Il nucleo del complesso vescovile paleocristiano di Zara, ideologia e cultura artistica tra Adriatico e Mediterraneo orientale (IV-X secolo), Il ruolo dell'autorità ecclesiastica alla luce di nuovi scavi e ricerche. Atti del convegno internazionale Bologna-Ravenna, 26-29 novembre 2007., Bologna, 2009., 311.

20 „Estin de kai eteroc naoc plysion autou eilymatikoc, y Agia Triac, kai epanw tou naou autou palin eteroc naoc dikyn katyhoumenwn, kai autoc eilymatikoc, eic on kai anerhontai dia kohliou". Konstantin VII. Porfirogenet, De thematibus et administrando imperio, cap. 29, 139 - 140. M. LONČAR, On the Description of the Churches, 239, bilj. 9. kada citira Konstantina Porfirogeneta, De administrando imperio, gl. 29, 138.

21 Pavuša Vežıć, Sveti Donat - Rotonda Sv. Trojstva u Zadru, Split, 2002., 11. Prijevod M. Lončara. Posljednji autor tretira različite oblike termina ta katechoúmena koji varira u izvorima, od kojih za catechumeneum smatra da je najpogodniji, s čime se slažem. M. LoNČAR, On the Description of the Churches, 235 - 242. Prije njega Jasna Jeličić-Radonić ( "Ta katechoumena” crkve Sv. Trojice [Sv. Donata] u Zadru, Diadora, sv. 14., Zadar, 1992., 345 - 355) analizira moguće funkcije catechumena unutar crkve sv. Trojstva u Zadru. 
prostor u kojem su bili katekumeni (jer više nema ni katekumenata odraslih), već ambijent oratorija ili ambijent namijenjen vladaru. ${ }^{22}$

$\mathrm{U}$ tom smislu, u iščitavanju funkcije galerija trebalo bi svakako istaknuti i sljedeće: nedavno je utvrđeno na osnovi pisanih svjedočanstava da su u razdoblju ranog srednjeg vijeka ili srednjeg bizantskog razdoblja prostori galerija u Bizantu, koje su išle uokolo cijele crkve formirajući slovo 'U”, odnosno prekrivajući donji nivo bočnih brodova i narteksa sve osim prezbiterija, rijetko bili namijenjeni ženama. Žene su tada zauzimale bočne brodove, muškarci glavni brod, a tek ponekad i rijetko su se žene uspinjale na gornje etaže. Štoviše, gornji kat crkve uglavnom je bio rezerviran za cara i caricu s pratnjom, koji su imali svoje carske odaje na galerijama, ali bio je namijenjen i za druge razne događaje kao što su sinode, pričesti, egzorcizmi, svećenička ređenja, razna primanja i svečana ugošćavanja, i sl. ${ }^{23}$ Čak i u spisu De cerimoniis nema nikakvih naznaka da su

22 T. F. Mathews, The Early Churches of Constantinople, 117 - 132. Detaljno o tome s nekoliko citata istočnih crkvenih otaca, povjesničara i liturgičara: Grgura Nazijanskog ( $S$ gornjeg kata čiste djevice skupa s udanim ženama prigibaju milostivo uho... o. 380. - 381. PG 37, 1255,), Sozomena (Kao što čujem, neki inzistiraju da je točno kako je jednom kad se narod skupio na bogoslužje, trudna žena pala s broda galerije i bila na mjestu mrtva, ali je vraćena u život skupnom molitvom sviju [za nju] te je bila spašena zajedno sčedom u utrobi; nakon 443., PG 67, 1425), Pavla Silentiarija (586. I tkogod se uspne naći će da su brodovi žena na svakoj strani slične onima odozdo; ali onaj koji ide povrh narteksa, na zapadu, nije kao ostala dva; 0. 563., Descriptio S. Sophiae), Prokopija (55. Dva su broda sa stupovima na svakoj strani i oni nisu odijeljeni od naosa nikakvim strukturalnim elementom već radije služe da potenciraju njegovu širinu; po dužini su jednaki [u krajevima] dok su po visini niži. Oni takoder imaju zaobljene svodove i zlatnu dekoraciju. Jedan od ovih parova brodova sa stupovima namijenjen je muškarcima za molitvu dok je drugi rezerviran za žene za istu radnju. Ali nema razlike izmedu ta dva broda niti se oni nešto razlikuju jedan od drugog već njihova jednakost služi da pojača ljepotu crkve i njihova sličnost služi kao ukras. Tko dakle može opisati galerije gynaeceuma ili nabrojiti obilje stupova ili dvorana sa stupovima kojima je crkva okružena? o. 550. - 560., De aedificiis), Evagrija Skolastika (1. S desne is lijeva, stupovi od tesalskog mramora postavljeni su u red pokraj njih [glavnih pilona], podržavajući putem drugih, slične stupove, galerije, dopuštajući onima koji toliko žele gledati dolje odvijanje obreda. 2. S tog mjesta carica, kada prisustvuje slavlju blagdana, svjedoči prinosu svetih misterija. 6. st.). Robert Francis TAFT, Women at church in Byzantium: where, when - and why?, Dumbarton Oaks Papers 52, Washington, D.C., 1998., 32 - 36.

23 Narratio de S. Sophia (svjedoči o gynaeceumu u donjem nivou bazilike, dok se na galerijama nalazi car: 3. S desne strane desnog gynaeceuma on [Justinijan] je napravio bazen u kojem se voda sakupljala do dubine od $23.4 \mathrm{~cm}$ i mostić preko kojeg je prolazio svećenik. 5. Tu je takoder napravio i metatorion, prekrasnu odaju prekrivenu zlatom tako da se tu može zadržati (odmoriti) kadgod dode u crkvu. Rukopis datiran u 8. - 9.st.), De Cerimoniis (opisuje obrede glavnih konstantinopolskih bazilika, a ovdje donosim obred Halkopratejske bazilike: 14. Vladari, nakon što su ušli u crkvu i odložili svoje torbice na sveti oltar, uputili su se s lijeve strane iste crkve i prolazili preko gynaeceuma iste crkve. 15. I u gynaeceumu su pričekali cijeli senat koji je odao počast vladarima. 16. i vladari su s patrijarhom i dvorjanima otišli preko luka prema svetom oltaru [kapele] Svete Škrinje...17. primanje se držalo u istom gynaeceumu crkve. Datirano u sredinu 10. st.). R. F. TAFT, Women at church, $37-46$. 
žene bile na galerijama. ${ }^{24}$ Upravo zato i pisac djela De administrando imperio za galerije u Sv. Trojstvu kaže da su crkva iznad crkve, što u osnovi odgovara funkcijama bizantskih ranosrednjovjekovnih galerija - one su, dakle, oratoriji kao zasebni sakralni ambijenti u odnosu na veći kongregacijski prostor. No, u ranobizantskom (ranokršćanskom) razdoblju situacija je ipak nešto drugačija. $\mathrm{U}$ tom dobu galerije su također namijenjene pripadnicima carskog dvora, ali još više ženama. One su pratile euharistiju s galerija i bočnih brodova donje etaže te su se upravo zbog žena prostori galerija u Bizantu nazivali uz već spomenuti izraz tà katekhoúmena i gynecei (iako se potonji izraz koristio i za donje, bočne brodove). Pretpostavlja se da je izraz tà katekhoúmena za galerije vjerojatno nastao u kasnoj antici zbog boravka katekumena do dijela pričesti ili za njihovo podučavanje, međutim zanimljivo je da nijedan zapis koji bi bio istovremen izrazu tomu ne svjedoči. U etimologiji i historiografiji izraza kojim su se nazivale gornje etaže crkava nalazimo čak nekoliko svjedočanstava. Tako se u Migneovoj Patrologia Graeca nalazi objašnjenje izraza catechumeina, gynaeceum i matroneo. Po tome je catechumeina gornji kat crkve koji se proteže na njezine tri strane. U njima su bile žene koje su stajale, za razliku od onih koje su sjedile u gynaikites. ${ }^{25}$ Izraz matroneo označava mjesto u crkvi rezervirano za žene, što se kod Latina ( $\mathrm{tj}$. u Zapadnoj crkvi) naziva još i partem mulierem. ${ }^{26}$ Po autoru Du Cangeu prostori catechoumeni ne bi bili rezervirani za katekumene, ni za njihovo poučavanje, ni za njihov boravak za vrijeme prvog dijela mise. Smatra da su catechoumeni ambijenti s kojih su žene promatrale liturgijsko slavlje. ${ }^{27}$

Sami povjesničari liturgije navode sljedeće: iako galerije u kasnoantičkom razdoblju na Istoku nisu namijenjene samo ženama i ne može se reći da su one kao ambijent rezervirane isključivo za žene, postoji više zapisa konstantinopolskih pisaca koji govore o prisutnosti žena na galerijama i tek o povremenim posjetima pripadnika carske obitelji. Car i carica također su ponekad pratili euharistijsko zbivanje na galerijama, u svojim ložama, ali čini se da u razdoblju od kasne

24 R. F. TAFT, Women at church, 28 - -87. Novija promišljanja istog autora donose spoznaje o genezi izraza catechumena za ambijent galerija u ranobizantskom razdoblju i o njegovu kontinuitetu kroz mlađa razdoblja na području Bizanta (bez obzira na to što katekumenat intenzivno opada kroz 6. i 7. st.) jer su na galerijama uz majke bila i djeca kojima je trebala poduka nakon ranog krštavanja. Katekumenat je svakako postojao i od 10. do 14. st. Tako na primjer De Cerimoniis I 21 (12) kaže da su neki od „barbarskih kandidata“ (djeca neortodoksnih obitelji) bila katehizirana prije i poslije krštenja. Robert Francis TAFt, When did the Catechumenate Die Out in Constantinople, ANA@MATA EOPTIKA, Studies in Honor of Thomas F. Mathews, Mainz, 2009., 288 - 295.

25 Patrologia Graeca (ur. J. P. Migne), Paris, 1857. - 1866), 112, 259. Prijevod: M. LonČAR, On the Description of the Churches, 241).

26 Patrologia Graeca (ur. J. P. Migne), Paris, 1857. - 1866), 112, 197 - 198.

27 Charles Du Frense Du Cange, Glossariae mediae et infimae Latinitatis, Paris, 1886., 180. 
antike pa do kraja ikonoklazma galerije prvenstveno bile namijenjene ženama. $S$ druge strane, u ranom srednjem vijeku galerije su većinom povezane s carskim funkcijama. ${ }^{28} \mathrm{R}$. F. Taft pa potom i J. F. Baldovin promišljaju kako u prvi tren izgleda kao da je brojnost žena veća u odnosu prema muškarcima, no treba imati na umu da su i djeca išla uz svoje majke te da se automatski stvara veća grupacija osoba tamo gdje su žene. No, jedini zapis koji smješta sve žene na galerije dosta je mlađeg postanka, iz 14. st., autora Ignacija iz Smolenska. ${ }^{29}$ Po svemu sudeći, očito je da u ranokršćanskoj fazi postoji veće odvajanje među vjernicima jer se žene penju na galerije (iako su one i u donjim etažama bočnih brodova), dok se u kasnijoj fazi, u ranom srednjem vijeku, odvajanje očituje više u staležu i položaju cara koji je redovito na galerijama u odnosu na ostale vjernike koji se većinom nalaze u prizemlju.

Može li se nešto od ovoga povezati s katedralom u Zadru?

Zahvaljujući zapisu C. F. Bianchija znamo da su se galerije zadarske katedrale tijekom povijesti nazivale matroneji, matronarii, a nekad i ginecei. ${ }^{30} \mathrm{Oba}$ su naziva arhaični termini: ginecei, kao što je objašnjeno, s grčkog govornog područja, a matroneum latinskog. ${ }^{31}$ Potonji nas u biti ne bi trebao čuditi s obzirom na to da je Crkva u Zadru pripadala zapadnoj matici i time provodila obrede rimske liturgije u svojoj sredini, no prvotni izraz (iako Bianchi navodi - nekad) ginecei upućuje na grčko govorno područje i time na priličnu arhaičnost termina. Jedino objašnjenje za to ležalo bi u konstataciji da je izraz za galerije nastao za vrijeme prevlasti Bizanta, dakle do rane romanike odnosno do graditeljskog zahvata kada je katedrala povišena (Sl. 6), što bi bio terminus ante quem, a on ujedno ukazuje na ipak veću mogućnost starijih/predromaničkih galerija. No, ako se pritom nijanse značenja izraza ginecei povežu ujedno s funkcijom, tada bi se mogla (ili štoviše i trebala) granica datacije pretpostavljenih galerija pomaknuti i u starije razdoblje!

Dakle, izraz ginecei označava prisutnost žena u dotičnom prostoru crkve, a ako se on referira na galerije, tada vrlo lako zaključujemo da su žene bile prisutne na galerijama. Odnosno, s obzirom na izvornike s konstantinopolskog

28 T. F. MATHEws, The Early Churches of Constantinople, 132.

29 R. F. TAFT, Women at church, 48 - 55; John Francis BALdovin, The Urban Character of Christian Worship. The Origins, Development and Meaning of Stational Liturgy, Roma, 1987., 176.

30 Carlo Federico BiAnCHi, Zara cristiana I, Zara, 1877., 122 - 123. Autor navodi još jedan naziv za galerije, očito lokalnog podrijetla, colonnette, zbog stupića koji formiraju ogradu.

31 M. Suić navodi da izraz matroneum potječe iz ravenskog kruga jer su se galerije S. Vitala u Raveni tako nazivale. U prevođenju termina tà katekhoúmena za galerije crkve sv. Trojstva kaže da bi se za njih mogao koristiti isti izraz, iako to više nije matroneum u „klasičnom“ smislu (jer je stekao pravo gradanstva). M. Suić, Zadar u „De administrando imperio“, 5 - 30. 
područja uviđamo da su galerije kao prostori unutar crkve bile namijenjene ženama tijekom kasne antike, odnosno do kraja ikonoklazma, da bi namjenu tih prostora preuzeli carski ceremonijali u ranom srednjem vijeku. Stoga se za galerije u tom razdoblju ipak koristi izraz tà katekhoúmena, kako je pisac nazvao i galerije crkve sv. Trojstva.

Termin matronej nagnao je akademika M. Suića na usporedbu s crkvama na području Ravene, no jedini ranokršćanski matronej u tome gradu nalazimo samo u Sv. Vitala. Ostale gradske crkve nemaju galerije. Sv. Vital je crkva koja je bila memorijalnog karaktera, ${ }^{32}$ a matronej, odnosno galerije išle su uokolo centralne jezgre, prateći obris poligonalnog oblika građevine, ali se nisu protezale preko prezbiterija, što je odlika crkava s Istoka. U tome se bitno razlikuju od situacije u crkvi sv. Trojstva u Zadru gdje se galerije protežu i preko prezbiterija. Ostala ravenska svetišta doista ne posjeduju galerije, dok mozaični prizori povorke svetica na lijevoj strani i svetaca na desnoj strani u bazilici S. Apolinare Nuovo odaju klasične podjele vjernika po spolu kao što to nalažu stavke rimskog obreda. ${ }^{33}$ Treba napomenuti da je investicija za izgradnju crkve sv. Vitala potekla od Juliusa Argentariusa - bankara, a ne od imperijalnih blagajni, dok sam car nikad nije bio u Raveni, pa tako ni u Sv. Vitalu. ${ }^{34}$ Stoga je u tom kontekstu vrlo zanimljivo da su galerije te ravenske centralne crkve ujedno matroneji, dakle ambijenti namijenjeni ženama za vrijeme liturgije, što je odlika Crkve na Istoku, pa i u tome možemo uvidjeti odjeke bizantskog načina ponašanja ili čak samog obreda na tlu Apeninskog poluotoka.

Raritetne su zapravo crkve na Zapadu koje posjeduju galerije. Osim crkve sv. Vitala u Raveni tu su još S. Lorenzo Maggiore (Sv. Lovre) u Milanu, Santa Agnese i San Lorenzo fuori le mura (Sv. Lovre van gradskih zidina) u Rimu. I one sve imaju memorijalni/funerarni karakter: u sklopu Sv. Lovre u Milanu imamo ambijente grobnica - ona je mauzolej teodozijanske dinastije, dok su Sv. Agneza i Sv. Lovre u Rimu klasični primjeri bazilika podignutih na cemeteriju. ${ }^{35}$ Imaju li,

32 James Allan Evans, The Age of Justinian, London, 2000., 224. Gradnja je započeta, kao i kod većine ravenskih crkava, za vrijeme Ostrogota.

33 Thomas Francis MAt hews, The Clash of Gods, a Reinterpretation of Early Christian Art, Princeton and Oxford, 1999., 171. „In the traditional view, the processional panels were created after Maximian took up his position in Ravenna (546) but before the death of Theodora (548), at a time when tensions flared between the imperial administration and the Roman Church during the Three Chapters Controversy." Joseph D. Alchermers, Art and Architecture in the Age of Justinian, Cambridge companion to the Age of Justinian (ur. M. Mass), Cambridge University Press, 2005., 346 - 347.

34 J. D. Alchermers, Art and Architecture in the Age of Justinian, $346-347$.

35 Pasquale Testini, Archeologia cristiana, Roma, 1980., 240 - 241; R. Krautheimer, Early Christian and Byzantin, 52, $80-81,270$. 
stoga, galerije neke veze $s$ funerarnim konotacijama ili obredima koji proizlaze iz Zapadne liturgije, ili je jednostavno riječ o pukoj koincidenciji, pitanje je koje bi bilo dobro dodatno istražiti.

Da su žene doista prisustvovale euharistiji na galerijama zadarske katedrale, ali sada u novovjekovnom razdoblju, napominje i nadbiskup Karaman u svom djelu koje je uputio Papi za vrijeme pastoralnog pohoda. U njemu tvrdi kako su žene zbog skromnosti ulazile u katedralu na bočna vrata i spiralnim se stepeništem, koje se nalazi u blizini, penjale na galerije. To se naravno ne odnosi na opis katedrale iz srednjovjekovnih vremena, ali govori o jakoj tradiciji u zadarskoj sredini jer su se žene još u doba baroka penjale na galerije. ${ }^{36}$

Zanimljiv u njezinoj historiografiji je i događaj iz 19. st.: kada je crkvu i Samostan sv. Marije Male 1808. preuzela francuska vlast i prenamijenila ih u bolničke svrhe, a redovnicama koje su bile privremeno smještene u biskupskom dvoru bila je dodijeljena cijela galerija katedrale za njihove svakodnevne uficije. ${ }^{37}$ To ujedno govori i o povezanosti galerija s biskupskom palačom, no nije poznato u koje doba se ona formirala. Bianchi navodi: „V’è un altro ingresso dall'episcopio, con una loggietta destinata ad uso dell'arcivescovo." ${ }^{\text {"38 }}$

$\mathrm{U}$ konstruktivnom smislu, ako razmatramo galerije u prvoj graditeljskoj fazi zadarske katedrale, tada bismo trebali uzeti u obzir djelomične sačuvane elemente iz tog vremena. Radi se o južnom bočnom zidu koji je bio rastvoren prozorima ranoromaničkih odlika. ${ }^{39} \mathrm{Njih}$ u biti siječe pod romaničkih galerija. Naravno da u prvi mah upada u oči jedna nelogičnost - ako su starije galerije bile na mjestu današnjih odnosno romaničkih, zar bi tada njihova nivelacija presijecala istovremene otvore? Jedino objašnjenje leži u činjenici da je razina poda onih starijih/ranokršćanskih (?) bila na nižoj visinskoj kvoti te da su prozori u principu sačuvani otvori ranokršćanskih galerija!

$\mathrm{U}$ prilog tome ide i visina sačuvanih antičkih stupova u bazilici koji su kao spolije iskorišteni u kasnoantičkoj bazilici. Njihova visina u skladu s nivelacijom kasnoantičke bazilike i nivelacijom pretpostavljenih galerija (niže od romaničkih, tj. niže od sačuvanih monofora) upućivala bi na gušći raspored stupova koji su po Jakšićevoj pretpostavci bili povezani arhitravima, no srednjovjekovna situacija raspolaže ipak arhivoltima. Nije naodmet spomenuti i stupove koji su kao spolije iskorišteni u konstrukciji ranoromaničke kripte. Tanji su i niži od stupova kolonade te načinjeni do običnog vapnenca (čime se isključuje instalacija ciborija,

\footnotetext{
C. F. BIANCHI, Zara cristiana, 122.

C. F. BIANCHI, Zara cristiana, 122 - 123.

C. F. BIANCHI, Zara cristiana,122.

P. VEžIĆ, Episkopalni kompleks u Zadru, 36.
} 
redovito podignuta od mramora). Na bočnoj strani jedan od njih ima usječen utor u koji je ulazila ploča nekog parapeta. Možda se radi upravo o stupovima koji su bili na galerijama, povezani međusobno pločama/plutejima, kao što je to na primjer slučaj kod bazilike sv. Dimitrija u Solunu.

Zanimljivo je da se po pitanju opsega same apside - šire od raspona srednjeg broda, katedrala u Zadru skupa s još nekim primjerima pokazala kao regionalna odlika, kao što je već prethodno rečeno. Uzori tomu pronađeni su u ugledanju kasnoantičkih graditelja (ili investitora - Crkve) u antičku baziliku koja se nalazila s južne strane Foruma, kojoj bi eksedra u punom promjeru bila šira od raspona glavnog broda. ${ }^{40}$ Pritom se uočava i konstatacija ili možda tek puka koincidencija da je ista profana bazilika imala i gornju etažu (galerije) koja se poput trjemova otvarala prema središnjoj dvorani!

U razmatranju o vremenu podizanja tzv. pastoforija uokolo ranokršćanske apside katedrale u Zadru autorica ovog rada uočava da su obje prostorije bile podignute tek nakon razdoblja ikonoklazma, odnosno vrlo vjerojatno tek sredinom 10. st. kada se isti ambijenti javljaju i na području Konstantinopola. ${ }^{41}$ Ujedno je istaknuta i dvoetažnost sjeverne prostorije ili protezisa. Iz njegove gornje etaže prolazilo se prema galerijama sjevernog bočnog broda katedrale. O tome svjedoči Bianchi, ali i crtež R. Eitelbergera. ${ }^{42}$ Naravno, nije materijalno utemeljeno da je protezis već u 10 st. bio dvoetažan odnosno povezan $s$ galerijama, no i tu nam pomažu elementi obreda s Istoka koji svoje datacije potkrjepljuju pisanim svjedočanstvima. U obrednicima tako nalazimo da su prostori sakristija (protezisa i diakonikona) nerijetko bili dvoetažni. ${ }^{43}$ Dvoetažne su tako i pastoforije nekih ravenskih crkava, na primjer San Vitala ili bazilike S. Giovanni Evangelista gdje su bočne prostorije bile u funkciji onodobnih knjižnica. ${ }^{44}$ Stoga je lako moguće da je i protezis katedrale u Zadru već izvorno bio dvoetažan, a time i povezan s galerijama, čime se dodatno podupire teza koja se provlači u raspravi. U tom slučaju napominjem i podatak

40 P. VEŽić, Zadar na pragu kršćanstva, 134.

41 Ana Mišković, The Influence of Ecclesiastical Reform on the Concept of Sacristy: The Episcopal Complex of Zadar ( $5^{\text {th }}-11^{\text {th }}$ Centuries); Hagiotheca. The impact of Church reforms on the construction of sacristy at the episcopal complex in Zadar from 5th till 11th century, Church Reforms and the Cult of Saints, Proceedings of the 5.th Hagiotheca conference (u tisku).

42 C. F. Bianchi, Zara cristiana, 122.

43 Robert Francis TAFT, Quaestiones disputatae: The Skeuophylakion of Hagia Sophia and Entraces of the Liturgy Revisited, Divine Liturgies -Human Problems in Byzantium, Armenia, Syria and Palestine, VII i VIII, Suffolk, 2001., 3 - 35, 53 - 87.

44 Charlotte Smith, The Side Chambers of San Giovanni Evangelista in Ravenna: Church Libraries of the Fifth Century, Gesta, Vol. 29, No. 1 (1990), 86 - 97. 
vezan za halkopratejsku baziliku gdje su se car i njegova svita penjali na galeriju stepenicama koje su bile na začelju Bogorodičine kapele, u dnu desnog bočnog broda jer crkva nije imala prostorije po boku svetišta. ${ }^{45}$

$S$ druge strane, P. Vežić navodi tradiciju postojanja galerija u zadarskoj sredini kod nekih drugih svetišta. No, poznate ranokršćanske gradske bazilike sv. Stjepan i sv. Toma pouzdano nisu imale galerije, ali im je zato masa bočnih zidova pouzdano bila probijena biforama, što je uspoređeno sa solunskim kulturnim krugom. ${ }^{46}$

Srednjovjekovna crkva sv. Marija Mala podignuta je kao longitudinalna trobrodna romanička bazilika. Poznato je da je ta romanička nastala na mjestu manje $\mathrm{e}^{47}$ (predromaničke?) crkve, a na temelju pronađenih fragmenata instalacija pretpostavlja se da je i ona nastala na mjestu još starije crkve (Sl. 7). $\mathrm{U}$ 16. st. trobrodna romanička bazilika u svom je produžetku dobila galerije koje su u 18. st. produžene i stekle rokoko formu (S1. 8). ${ }^{48}$ Galerije su koristile redovnice za svoje pobožnosti.

Crkva Samostana sv. Nikole tijekom stoljeća mijenjala je više puta svoje građevinsko ruho (Sl. 9). Crkva je skupa sa samostanom podignuta tijekom 14. st. na mjestu starije (srušene) te dana na službu klarisama. Potom je u baroku, 1760., srušena do temelja i iznova izgrađena (S1. 10). Jedino su stariji pročelni i istočni bočni zid djelomično sačuvani u smislu da su prilikom akcije preuređenja visoko nadograđeni. ${ }^{49}$ "Zapadni zid, obje kolonade $s$ galerijama i sklop svetišta sa sakristijom iz temelja su podignuti kao posve nova struktura izgrađena prema projektima koje je izradio zadarski arhitekt A. Piovesan." ${ }^{\text {" }} \mathrm{U}$ zidu te barokne crkve pronađena je ranokršćanka spolija. Ipak, to ne može biti argument za tvrdnju da je ona in situ ni da je već u kasnoj antici na tom mjestu postojalo određeno kršćansko svetište. U zidu baroknih galerija iz 18. st. pronađeni su i kapiteli tipa acantus spinosa iz 11. st., što bi također moglo upućivati na možebitnu stariju crkvu na istom mjestu. ${ }^{51}$ Stoga, o starijim galerijama, moguće srednjovjekovnima, nemamo podataka, no visina kasnosrednjovjekovnog pročelnog zida i izgradnja baroknih galerija mogli bi upućivati na kontinuitet tog ambijenta u mlađim vremenima.

45 T. F. Mathews, The Early Churches of Constantinople, 31.

46 P. VEŽIĆ, Zadar na pragu kršćanstva, 134.

47 C. F. BIANCHI, Zara cristiana, 315.

48 P. VEŽić, Po čemu je u 10. st. katedrala u Zadru, 310.

49 Pavuša Vežıć, Crkva i samostan Sv. Nikole u Zadru, Prilozi povijesti umjetnosti u Zadru (Prijateljev zbornik, II)., Split, 1992., 313.

50 P. VEŽıć, Crkva i samostan Sv. Nikole, 313.

51 P. VEžıć, Crkva i samostan Sv. Nikole, 313 - 315. 
Iz prethodna dva primjera (bazilike sv. Marije Male i sv. Nikole) proizlaze dvije sigurne i vrlo zanimljive činjenice: prva je da se radi o crkvama koje su u pogledu funkcije samostanske crkve namijenjene redovnicama. A druga jest da obje crkve imaju galerije, ako ne ranije, tada sigurno u baroknom razdoblju, a upravo se za taj ambijent u zadarskoj sredini koristio izraz matronej/gynecei u smislu prostora za žene na galerijama u katedrali.

\section{ZAKLJUČAK}

Upravo zbog arhaičnih termina koji su korišteni u povijesti zadarske katedrale sve do 19. st., a koji su bili karakteristični za ranokršćansko razdoblje (matronej i gynecei), odnosno zbog funkcija na koje nas ti termini upućuju, a to je prisutnost žena za vrijeme mise na galerijama, smatram da se može usvojiti pretpostavka Pavuše Vežića o galerijama u katedrali već u doba kasne antike. ${ }^{52}$ Možda su se žene za vrijeme mise nalazile i u bočnim brodovima, što je odlika Crkve na Zapadu, ali o tome ne posjedujemo nikakvih saznanja. Stoga je važno da zadarski kanonik Bianchi u 19. st. izrazom gyneceum naziva upravo galerije. Svakako je termin gyneceum simptomatičan jer u zadarskoj sredini vjerojatno ne bi zaživio u vrijeme romaničkog razdoblja i prevlasti/nadmoći rimske liturgije. Ta činjenica može ukazivati da se uz rimski obred, koji je bez sumnje glavni obrazac obavljanja liturgije u zadarskoj sredini, vjerojatno već u ranoj fazi ubacuju dijelovi i stavke konstantinopolskog obreda. Penjanje žena na galeriju pojava je isključivo vezana za Istok, odnosno konstantinopolsku liturgiju, i to, kao što je napomenuto u raspravi, prvenstveno u ranobizantskoj fazi. Ako je zadarska ranokršćanska katedrala posjedovala galerije, po tome je u njoj slijedila podjela vjernika po bizantskom obredu, čime se dodatno potkrjepljuje teza o ambivaletnom ozračju zadarske Crkve. 


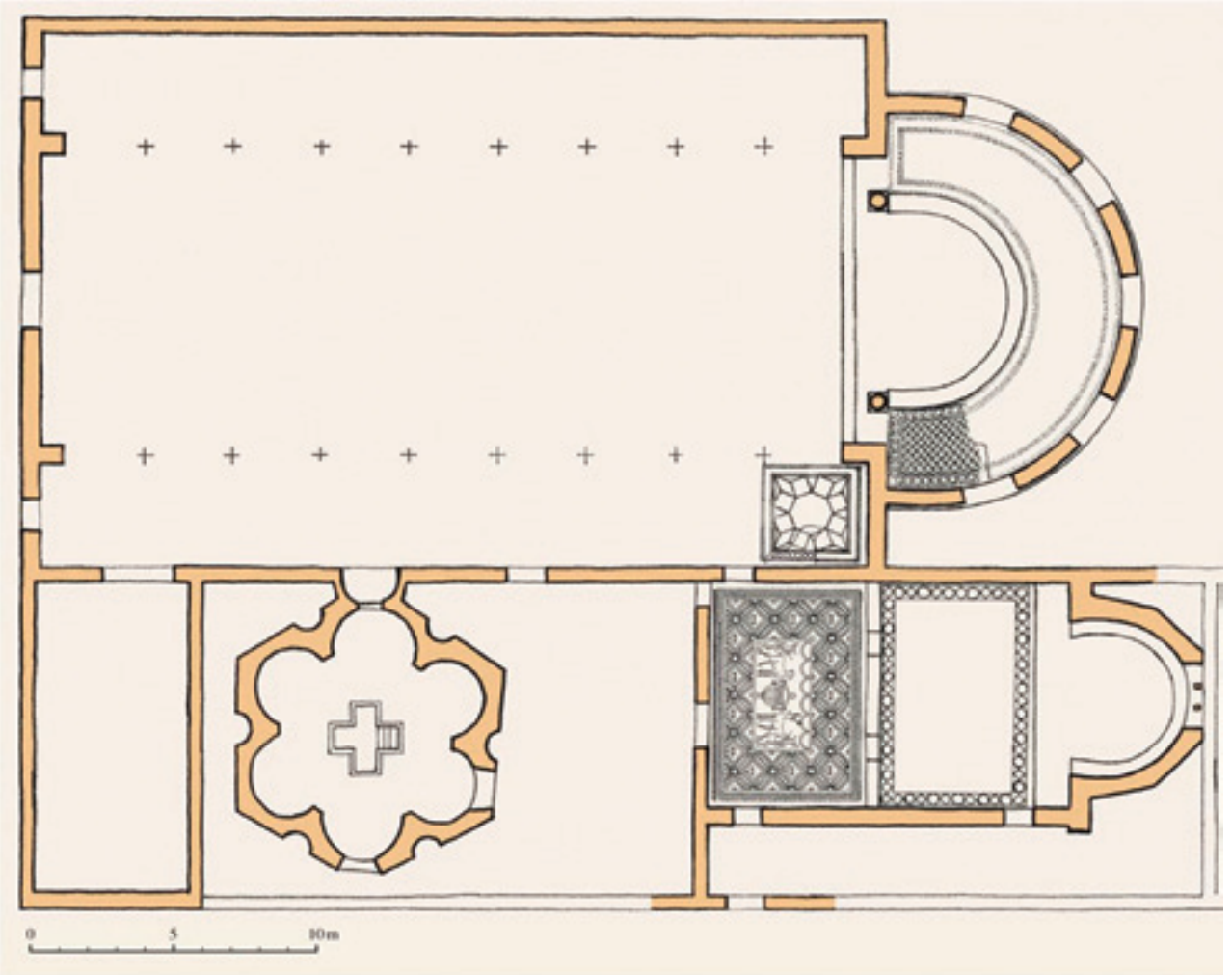

SLIKA 1. Grafička rekonstrukcija tlocrta ranokršćanskog episkopalnog sklopa u Zadru. (Pavuša VEŽIĆ, Zadar na pragu kršćanstva. Arhitektura ranoga kršćanstva u Zadru i na zadarskome području, Zadar, 2005.)

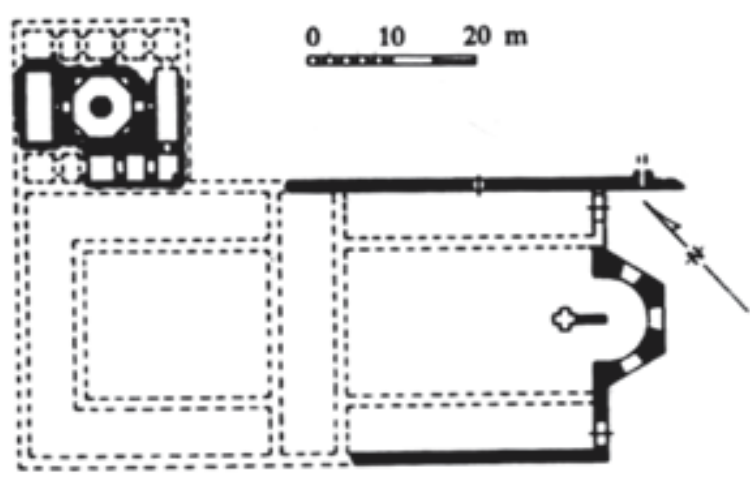

Chalkoprateia Basilica

SLIKA 2. Tlocrt Halkopratejske bazilike u Konstantinopolu. (Thomas Francis Mathews, The Early Churches of Constantinople: Architecture and Liturgy, London, 1971.) 


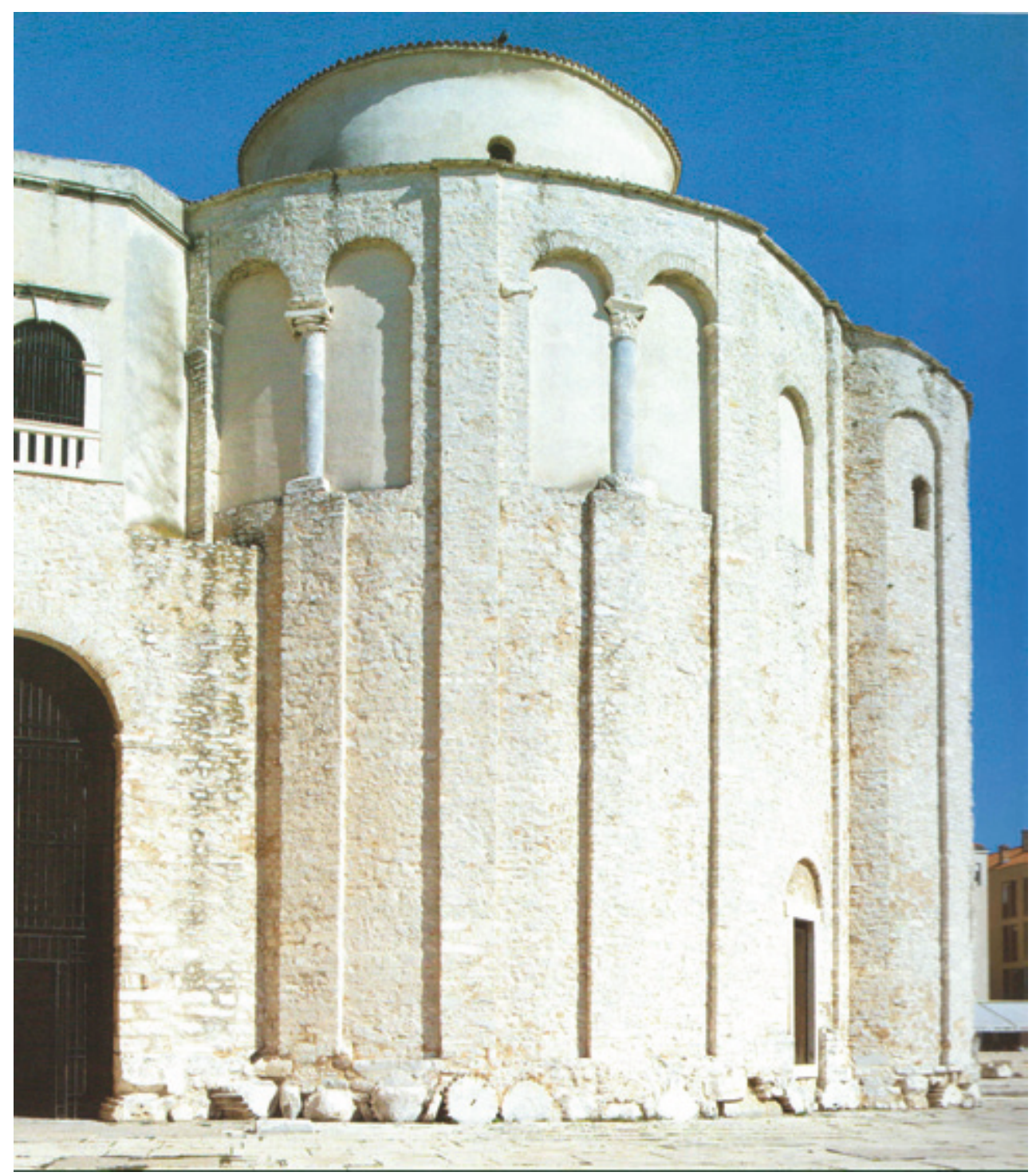

Slika 3. Pogled na rotondu Sv. Trojstva / crkvu Sv. Donata u Zadru. (Pavuša vezice Sveti Donat Rotonda Sv. Trojstva u Zadru, Split, 2002.) 


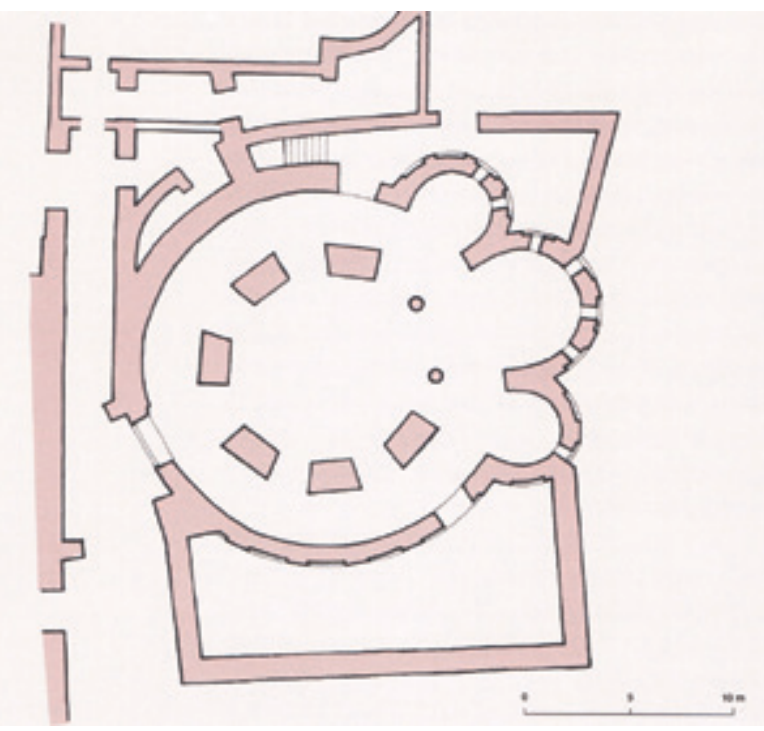

SliKA 4. Grafička rekonstrukcija tlocrta prizemlja kompleksne rotonde Sv. Trojstva u Zadru. (Pavuša Vežıć, Zadar na pragu kršćanstva. Arhitektura ranoga krš́áanstva u Zadru i na zadarskome području, Zadar, 2005.)

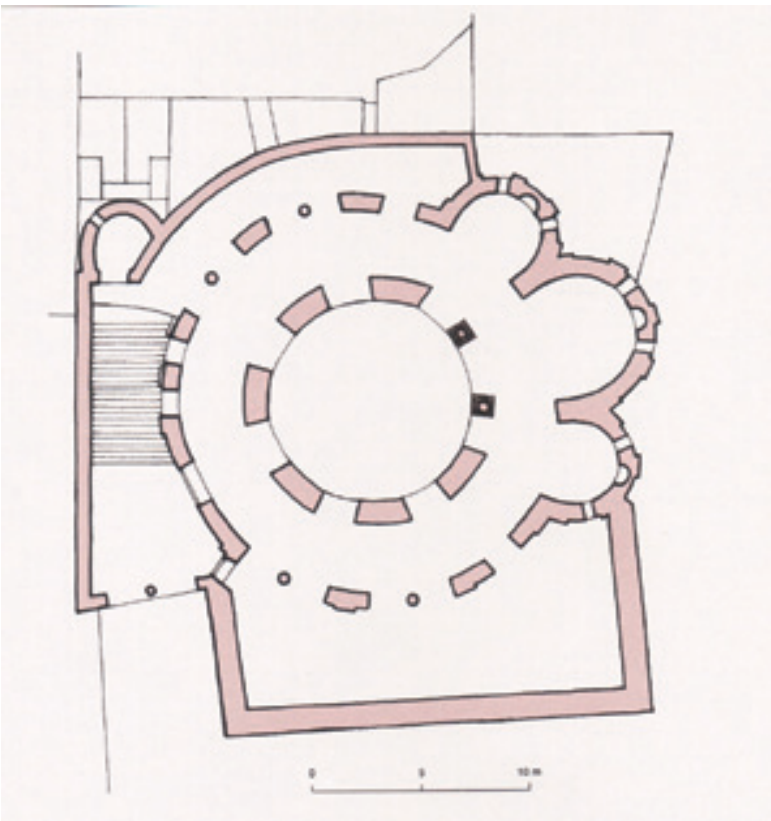

SLIKA 5. Grafička rekonstrukcija tlocrta prvog kata - oratorija kompleksne rotonde Sv. Trojstva u Zadru. (Pavuša VEžić, Zadar na pragu kršćanstva. Arhitektura ranoga kršćanstva u Zadru i na zadarskome području, Zadar, 2005.) 

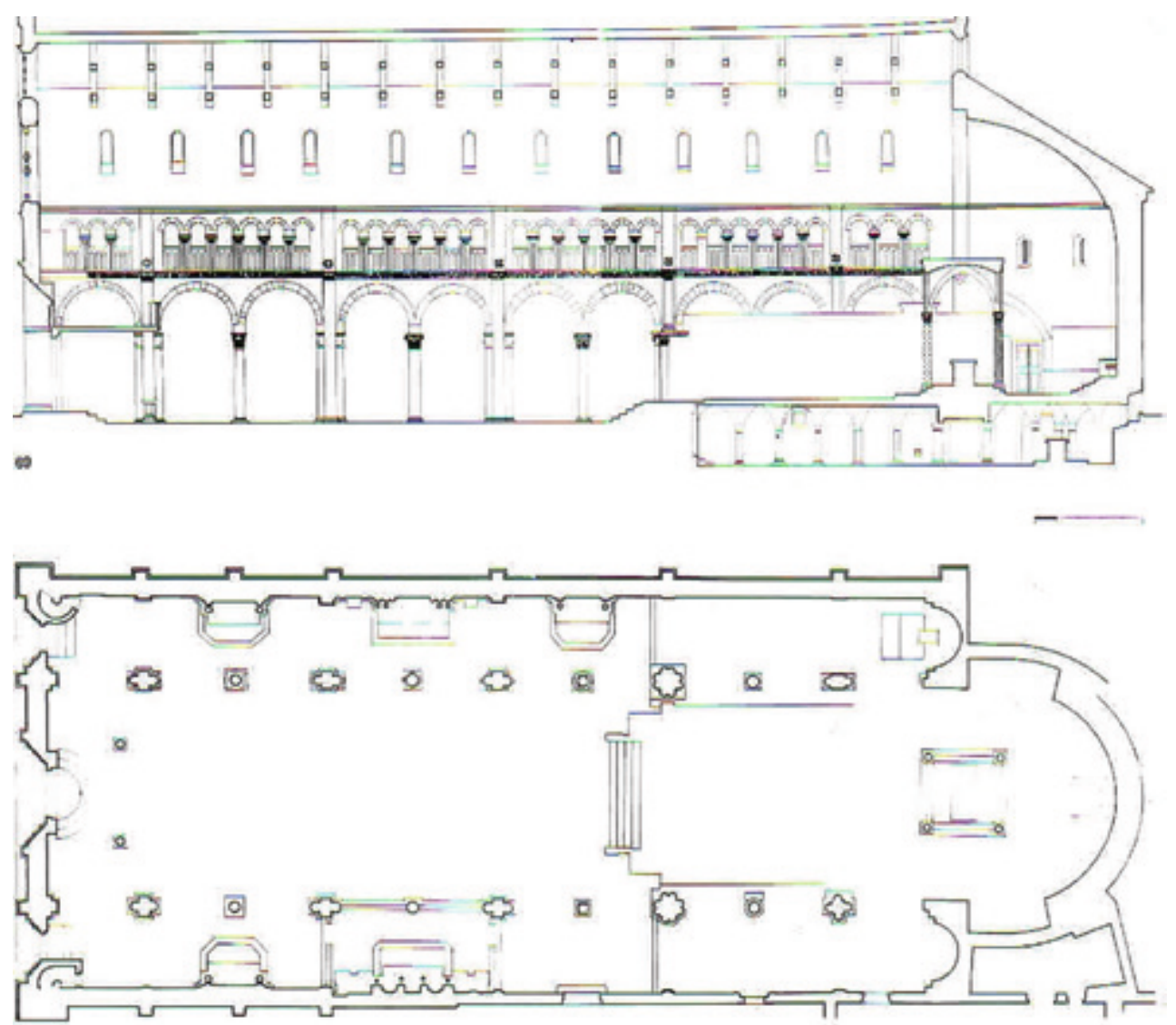

SLIKA 6. Tlocrt i presjek romaničke katedrale u Zadru. (Sjaj zadarskih riznica, ur. Miljenko Domijan - Ivo Petricioli, Pavuša Vežić, Zadar, 1990.) 


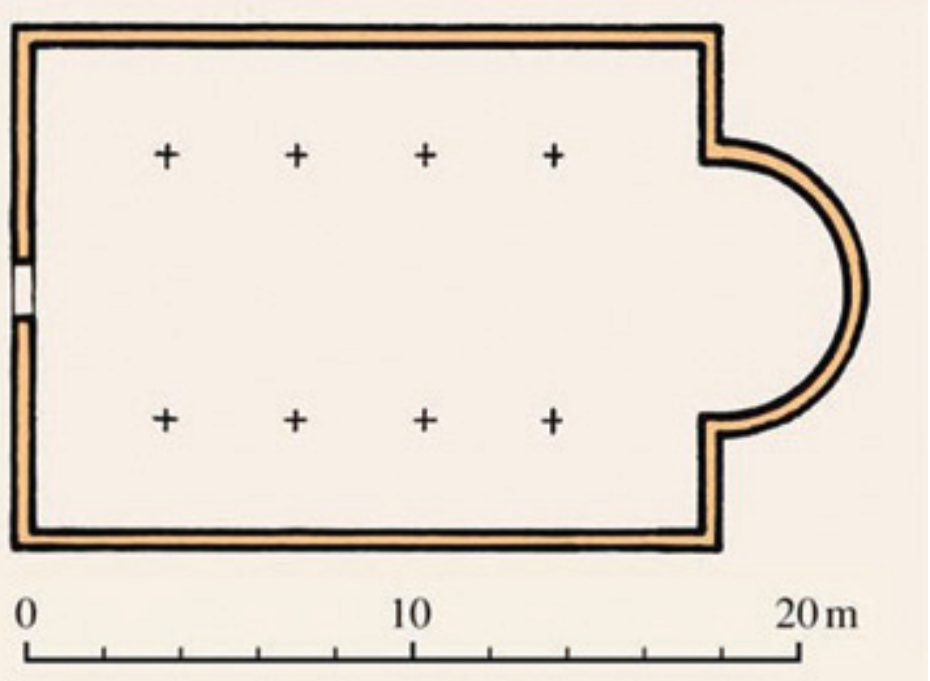

SLIKA 7. Graficka rekonstrukcija tlocrta bazilike Sv. Marije u Zadru. (Pavuša Vežıć, Zadar na pragu kršćanstva. Arbitektura ranoga kršćanstva u Zadru i na zadarskome području, Zadar, 2005.)

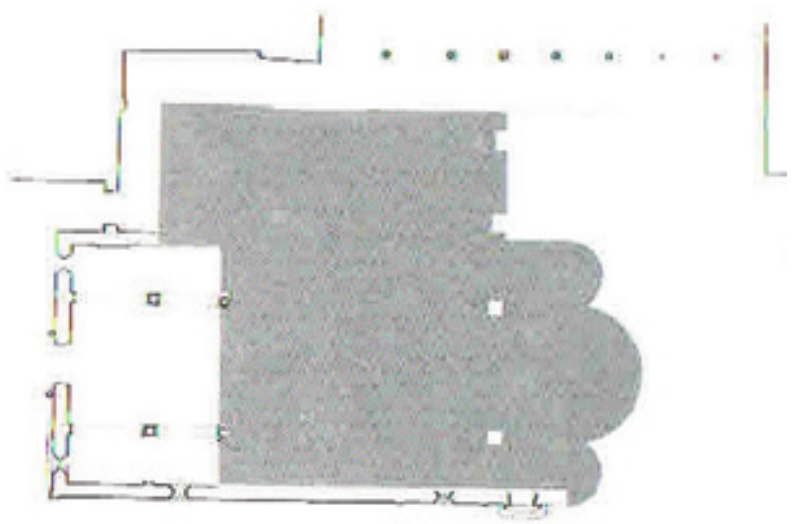

SLIKA 8. Tlocrt renesanse faze bazilike Sv. Marije u Zadru. (Sjaj zadarskih riznica, ur. Miljenko Domijan - Ivo Petricioli, Pavuša Vežıć, Zadar, 1990.) 

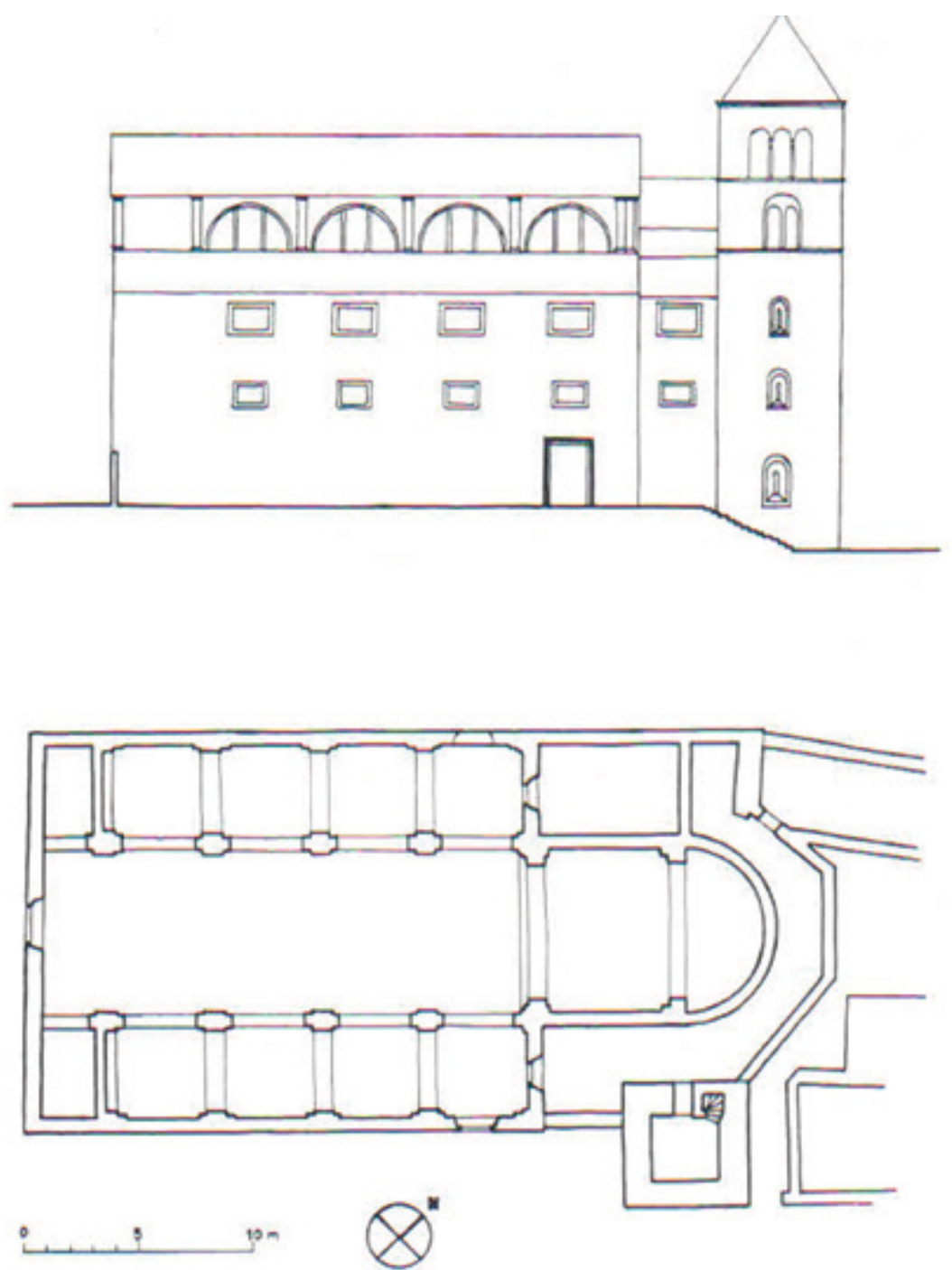

SLIKA 9. Tlocrt i pogled na južni bočni zid crkve Sv. Nikole u Zadru. (Pavuša Vežıć, Crkva i samostan Sv. Nikole u Zadru, Prilozi povijesti umjetnosti u Zadru (Prijateljev zbornik, II)., Split, 1992.) 

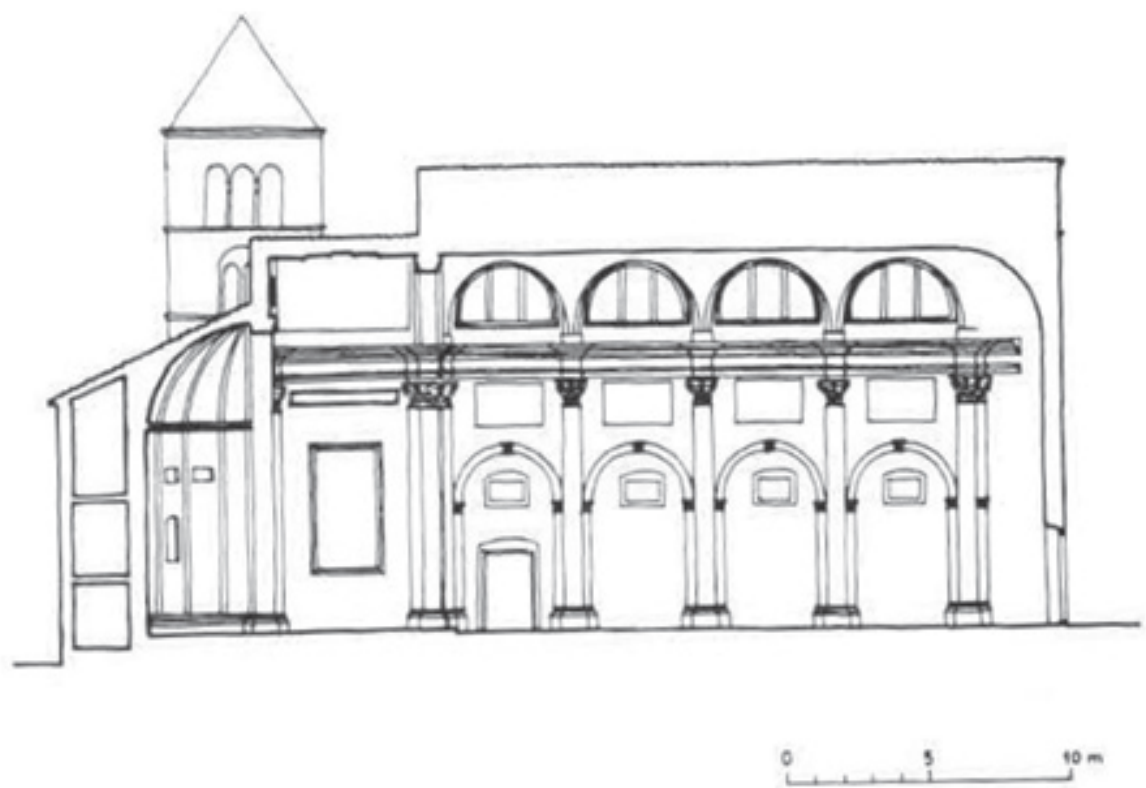

SLIKA 10. Presjek crkve Sv. Nikole u Zadru. (Pavuša Vežıć, Crkva i samostan Sv. Nikole u Zadru, Prilozi povijesti umjetnosti u Zadru (Prijateljev zbornik, II)., Split, 1992.) 


\section{Ana MIŠKOVIĆ}

\section{ABOUT THE MATRONEUM OF ZADAR CATHEDRAL}

\section{SUMMARY}

In his work "In What Manner Did the 10th Century Zadar Cathedral Resamble the Chalcopratiae Basilica in Constantinople", Pavuša Vežić assumes that this church is a Romanized form of the early Christian one with its medieval interpolations. The author believes that the Cathedral of Zadar, along with its primary architectural styles such as a longitudinal three-nave basilica, or a chapel at the rear of the northern side nave, could even resemble the famous Constantinople Chalkoprati Basilica in having galleries. This is supported by the very archaic terms which, in the history of Zadar Cathedral, were used until the 19th century and which were characteristic of the early Christian period: matroneum and gyneacei. They must refer to the functions derived from the Byzantine rite, or to the placement of the worshippers during the liturgical service, mainly the placement and presence of women in the galleries. The term gynaeceum is so symptomatic as it would probably not have come to life in the Zadar area during the Romanesque period and the dominance/supremacy of the Roman liturgy. This may indicate that along with the Roman service, which is undoubtedly the main form of ceremony in the Zadar area, probably very early parts and items of the Constantinople rite were introduced. Women sitting in the gallery is characteristic of the beginning of the Byzantine period. If we accept the assumption that cathedral galleries date back to late antiquity, the ambivalent atmosphere of Zadar Cathedral could be corroborated further.

The galleries in Zadar churches reappeared only in the early Middle Ages. We find them in the Basilica of St. Mary's Birth's Church and the Church of St. Nicholas, which belonged to a monastery complex. The former is intended for the Benedictines and the latter for the Poor Clares. This fact indicates that closed female religious orders also used galleries to accommodate nuns during the service. This confirms the influence that is likely to have come from the cathedral itself.

Keywords: matroneum, oratory, galleries, cathedral, early Christian basilica. 
